\title{
THE IMMUNOPHENOTYPE OF ADULT T ACUTE LYMPHOBLASTIC LEUKEMIA IN MOROCCO
}

\author{
A. Lahjouji i, , **, F. Bachir ${ }^{1}$, S. Bennani ${ }^{1}$, A. Quessar ${ }^{2}$, S. Amzazi ${ }^{3}$ \\ ${ }^{1}$ Laboratory of Flow Cytometry, National Institute of Hygiene, Rabat 769, Morocco \\ ${ }^{2}$ Service of Hematology and Pediatric Oncology, Hospital 20 Août, Casablanca, Morocco \\ ${ }^{3}$ Mohamed V-Agdal University, Faculty of Sciences, UFR Biochemistry and Immunology, Rabat 769, Morocco
}

Background: There is paucity of detailed studies of adult $\mathrm{T}$ cell acute lymphoblastic leukemia (T-ALL) in developing countries reflecting the condition of these patients including clinical and biological features. Objective: This study was carried out to analyze the immunophenotypic characteristics of 40 Moroccan patients with T-ALL and its association with biological and clinical features. Patients and Methods: Between 2006 and 2009, 130 adult patients diagnosed with acute lymphoblastic leukemia (ALL) were immunophenotyped by 3-color flow cytometry using a panel of monoclonal antibodies. Cases presenting features of a T-lineage phenotype were subjected to detailed analysis including immunophenotypic, clinical and biological parameters. Results: Proportion of T-ALL among ALL Moroccan patients was 31.0\%. Median age of patients was 28 years. Twenty-nine patients were females and 11 were males. $45.0 \%$ of patients $(18 / 40)$ had features of immature T-ALL stages (pro-T and pre-T ALL), 30.0\% (12/40) of CD1a+ cortical T-ALL stage and $25.0 \%(10 / 40)$ had a characteristic phenotype of medullary T-ALL. The frequencies of progenitor cell markers CD10, CD34 and TdT expression were $14.0 ; 57.5 \%$ and $50.0 \%$ respectively. The aberrant expression of B lineage associated antigen CD79a were positive in $20.5 \%$ of the cases and the aberrant expression of myeloid antigens CD13 and/ or CD33 was found in $22(55.0 \%)$ cases. No significant association was encountered between TdT, CD34 or myeloid antigens positivity and high risk features at presentation as age, sex, and white blood cells. However, myeloid antigens (CD13 and/or CD33) was significantly associated with T-cell maturation stages $(p=0.009)$. Conclusion: To the best of our knowledge, this is the first report from North Africa of immunophenotypic study on adult T-ALL. Our findings indicate that the proportion of T-ALL among ALL in Morocco is similar to that reported in others Mediterranean countries like France and Italy and that myeloid-associated antigens expression is frequently associated with immature immunophenotype.

Key Words: adult $\mathrm{T}$ cell acute lymphoblastic leukemia, immunophenotypic analysis, immunological subtypes, myeloid and T-cell antigens.

Acute lymphoblastic leukemia (ALL) represents a biologically and clinically heterogeneous group of diseases characterized by the accumulation of immature lymphoid cells within the bone marrow (BM) and Iymphoid tissues. ALL represents about $80 \%$ of acute leukemias in childhood, where it is the most frequent malignancy, and accounts for about $20 \%$ of adult acute leukemias [1].

Early classification systems for acute leukemias were based only on morphological and cytochemical investigations. Morphology still plays a central role, but current World Health Organization (WHO) classification of tumors of hematopoietic and lymphoid tissues incorporates also immunophenotyping, cytogenetic and molecular characteristics that contribute towards defining biologically and clinically relevant leukemia subsets [2].

Flow cytometric immunophenotyping of ALL is fundamental in the modern diagnosis and treatment of acute leukemia for several reasons. First, the utilization of larger panels of monoclonal antibodies to B-cell, T-cell and myeloid as well as non-lineage-restricted antigens allows characterization of blast cells by line-

Submitted: January 20, 2015.

*Correspondence: Fax: 00212537772067 ;

E-mail: lahjouji_ali@yahoo.fr

Abbreviations used: ALL - acute lymphoblastic leukemia; $A M L$ - acute myeloid leukemia; BM - bone marrow; ETP - early T-precursor origin; MPO - myeloperoxidase; PB - peripheral blood; T-ALL - T cell acute lymphoblastic leukemia; T-LBL - T cell lymphoblastic lymphoma.

**Institution to which the work should be attributed: National Institute of Hygiene, Rabat 769, Morocco. age assignment, evaluation of cell maturation, and assessment of phenotypic aberrations. Second, immunophenotyping is also essential for recognizing several subtypes of acute myeloid leukemia (AML) (e.g., minimally differentiated, myeloperoxidase-negative AML and acute megakaryoblastic leukemia) and mixed phenotype acute leukemia. Finally, immunophenotyping is important for monitoring the response to treatment, including detection of minimal residual disease and for identifying markers with prognostic implication [3].

Malignant lymphoid neoplasms involving the presence of neoplastic immature lymphoid cells of $\mathrm{T}$-cell lineage in both the blood and the BM have been designated as precursor $T$ cell acute lymphoblastic leukemia (T-ALL)/lymphoblastic lymphoma (T-LBL) in the recently published WHO classification for hematologic neoplasms. When there is extensive involvement in both the BM and the blood, the preferred term is leukemia. However, if a mass lesion is present with minimal blood and BM involvement, the appropriate term is lymphoma [2].

The most important studies about T-ALL/LBL come from developed countries with regard to their distribution according to the classical intrathymic differentiation compartments, clinical features, description of prognostic factors as well as the outcome. The purpose of this study is to determine, by flow cytometry, the frequency and immunophenotypic features of Moroccan patients with T-ALL. The immunophenotypic findings were correlated to biological and clinical features in comparison with B-lineage ALL. 
MATERIALS AND METHODS

Patients. From January 2006 to December 2009, immunophenotyping was successfully performed in 130 consecutive adults ( $\geqslant 18$ years) newly diagnosed with ALL (other than L3 subtypes) at the Hematology and Oncology Hospital, Casablanca, Morocco. Cases presenting features of a T-lineage phenotype were subjected to detailed analysis including immunophenotypic, clinical and biological parameters. ALL diagnosis was performed on May-Grunwald - Giemsa smears. BM or peripheral blood (PB) samples were collected, prior to treatment, on ethylenediaminetetraacetic acid (EDTA) tubes. All patients were consented to the routine laboratory and hospital procedures including blood and BM studies. Patients were analyzed for age, gender, morphological $F A B$ subtypes, white blood cells (WBC) count, platelets count and hemoglobin levels, lymphoadenopathy, splenomegaly, hepatomegaly and cytogenetic data.

Flow cytometry. All EDTA-anticoagulated PB/ $\mathrm{BM}$ samples were immediately transported to the $\mathrm{Cy}$ tometery Laboratory of the National Hygiene Institute of Morocco for immunophenotyping. All the samples were evaluated by flow cytometry, using CD45 expression vs side scatter to analyze the blast cell population as described earlier [4]. T-lymphoid antigens included CD1a, CD3, CD4, CD5, CD7 and CD8; B-lymphoid antigens included CD10, CD19, CD22, and cytoplasmic CD79a. Myeloid antigens were myeloperoxidase (MPO), CD13 and CD33. Precursor-cell antigens analyzed were CD34, HLA-DR, and TdT. Positive staining was defined as at least $20 \%$ of blast cells showing expression of the marker of interest. T-lineage ALL patients were diagnosed based on the positive expression of CD3 (cytoplasmic and/or surface) and were classified further into three maturational stages that were defined as immature T-ALL stage (pro-T and pre-T ALL): sCD3 ${ }^{-}, \mathrm{CCD}^{+}, \mathrm{CD}^{+}, \mathrm{CD}^{-} \mathrm{a}^{-}, \mathrm{CD}^{+}$and/ or $\mathrm{CD}^{+}$; cortical T-ALL stage: positive for CD1a (irrespective of other markers), and medullary T-ALL: positive for surface CD3 and negative for CD1a (irrespective of other markers).

Statistical analysis. The analysis was done using SPSS 17.0 version. The characteristics of the patients were compared by the exact $\chi^{2}$ or Fisher tests. All tests were 2 -sided with a $p$ value of less than 0.05 indicating a statistically significant difference.

\section{RESULTS AND DISCUSSION}

Immunophenotypic findings. Of the $130 \mathrm{ALL}$ cases immunophenotyped, 40 (31.0\%) cases were classified as having T-ALL and 84 (64.5\%) cases were classified as having B-ALL disease. Mixed acute leukemia comprised $6(4.5 \%)$ cases and were dropped from further evaluation. Table 1 summarizes the frequencies of antigens expression found in 40 patients diagnosed with T-ALL in comparison with B-ALL. The cytoplasmic CD3 and CD7 were the only surface T-cell antigens expressed by all cases $(100.0 \%)$, followed by CD5 (82.0\%), surface CD3 (62.5\%), CD4 (34.0\%) and CD8 (31.5\%). Co-expression of CD4 and CD8 was observed in $21.0 \%$ of cases whereas lack of expression of them both was observed in $55.0 \%$ of cases. CD10 was found in 5 cases (14.0\%) and absent in $31(86.0 \%)$ of 36 cases tested for CD10. CD34 (57.5\%), TdT (50\%) and HLA-DR positivity (25.0\%) were significantly much lower in T-ALL than those in B-ALL (77.5; 84.0 and $100.0 \%$, respectively). The aberrant expression of B-lineage associated antigen CD79a was positive in $20.5 \%$ of the cases and the aberrant expression of myeloid antigens CD13 and/ or CD33 was found in 22 cases $(55.0 \%)$, more frequently CD13 than CD33. Indeed, CD13 was observed in $17(42.5 \%)$ patients, whereas CD33 was observed in $10(25.0 \%)$ cases. Both CD13 and CD33 antigens were expressed in $5(12.5 \%)$ cases. No difference was observed in myeloid antigen expression between T-ALL and B-ALL subgroups ( $55.0 \%$ vs $52.5 \%$, $p=0.744)$. According to surface antigens expression by leukemic cells, $45.0 \%$ of patients $(18 / 40)$ had features of immature T-ALL phenotype (pro-T and pre-T ALL), 30.0\% (12/40) of cortical T-ALL subtype and $25.0 \%$ (10/40) of medullary T-ALL subtype. Early $\mathrm{T}$ cell precursor-ALL, a very poor prognosis subgroup defined by its associated distinctive immunophenotype (CD1 $\mathrm{a}^{-}, \mathrm{CD}^{-}, \mathrm{CD} 5$ weak with stem-cell/myeloid markers) $[5,6]$, was found in $6(15.0 \%)$ cases.

Table 1. Number of patients and frequency (\%) cells with individual marker expression in B-ALL and T-ALL

\begin{tabular}{|c|c|c|c|}
\hline $\mathrm{CD}$ & $\mathrm{B}-\mathrm{ALL}(\mathrm{n}=84)$ & T-ALL $(n=40)$ & $p$ \\
\hline CD1a & - & $12(31.5)$ & - \\
\hline CytCD3 & $0(0.0)$ & $40(100.0)$ & $<0.001$ \\
\hline CD3 & $0(0.0)$ & $25(62.5)$ & $<0.001$ \\
\hline CD4 & - & $13(34.0)$ & - \\
\hline CD5 & - & $32(82.0)$ & - \\
\hline CD7 & $3(3.5)$ & $40(100.0)$ & $<0.001$ \\
\hline CD8 & - & $12(31.5)$ & - \\
\hline CD10 & $51(60.5)$ & $5(14.0)$ & $<0.001$ \\
\hline CD13 & $29(36.5)$ & $17(42.5)$ & 0.507 \\
\hline CD19 & $84(100.0)$ & $1(2.5)$ & $<0.001$ \\
\hline CD22 & $84(100.0)$ & $2(5.5)$ & $<0.001$ \\
\hline CD33 & $24(29.0)$ & $10(25.0)$ & 0.649 \\
\hline CD34 & $65(77.5)$ & $23(57.5)$ & 0.023 \\
\hline CD45 & 72 (91.0) & $36(97.0)$ & 0.433 \\
\hline CD79a & $78(100.0)$ & $7(20.5)$ & $<0.001$ \\
\hline TdT & $68(84.0)$ & $19(50.0)$ & $<0.001$ \\
\hline HLA-DR & $84(100.0)$ & $10(25.0)$ & $<0.001$ \\
\hline $\mathrm{CD}^{+} / \mathrm{CD}^{+}$ & - & $8(21.0)$ & - \\
\hline $\mathrm{CD}^{-} / \mathrm{CD} 8^{-}$ & - & $21(55.0)$ & - \\
\hline $\mathrm{CD}^{\prime}{ }^{+}$and/or $\mathrm{CD} 33^{+}$ & $42(52.5)$ & $22(55.0)$ & 0.744 \\
\hline $\mathrm{CD} 3^{+} / \mathrm{CD} 3^{+}$ & $10(12.5)$ & $5(12.5)$ & 1.0 \\
\hline
\end{tabular}

Relationship between immunophenotype and disease characteristics

Clinical characteristics by lineage. Baseline characteristics of T-ALL patients compared with B-ALL patients are summarized in Table 2. T-ALL and B-ALL significantly differed in their presentation. T-cell disease was more commonly seen in males $(72.5 \%$ vs $52.5 \%, p=0.033$ ). T-cell disease was more common in the 18 to 35 years age group $(75.0 \%$ vs $56.0 \%$, $p=0.041$ ). There was an association between T-cell disease and a high WBC with $52.5 \%$ of T-ALL patients having a WBC more than $50000 / \mu$ compared with $31.0 \%$ of $\mathrm{B}$-cell patients $(p=0.021)$. There was no statistically significant difference between groups in terms of splenomegaly and hepatome- 
galy frequencies whereas lymphadenopathy seems to be associated with the T-phenotype rather than with the B-phenotype (84.0\% vs $57.0 \%, p=0.014)$. Cytogenetic data are available for 96 cases including 71 cases of B-ALL and 25 cases for T-ALL. Normal diploid caryotypes were more frequently in T-lineage ALL patients than in B-lineage ALL patients $(55.0 \%$ vs $29.0 \% ; p=0.035)$. The immunophenotype of leukemic blasts from patients with $t(9 ; 22)$ and with $t(4 ; 11)$ were restricted to B-ALL.

Table 2. Comparison of clinical and biological features of Moroccan adult patients with B-ALL and T-ALL

\begin{tabular}{|c|c|c|c|c|}
\hline Variable & $\begin{array}{c}\text { All patients, } \\
\mathrm{n}(\%) \\
124(100.0)\end{array}$ & $\begin{array}{c}\text { B-ALL, } \\
n(\%) \\
84(67.5)\end{array}$ & $\begin{array}{c}\text { T-ALL, } \\
\text { n (\%) } \\
40(32.5)\end{array}$ & $p$ \\
\hline \multicolumn{5}{|l|}{ Age } \\
\hline Median & $31(18-66)$ & $34(18-66)$ & $28(18-66)$ & \\
\hline$\leqslant 35$ & $77(62.0)$ & $47(56.0)$ & $30(75.0)$ & 0.041 \\
\hline$>35$ & $47(38.0)$ & $37(44.0)$ & $10(25.0)$ & \\
\hline \multicolumn{5}{|l|}{ Sex } \\
\hline male & $73(59.0)$ & $44(52.5)$ & $29(72.5)$ & 0.033 \\
\hline female & $51(41.0)$ & $40(47.5)$ & $11(27.5)$ & \\
\hline \multicolumn{5}{|l|}{ FAB } \\
\hline ALL L1 & $11(9.0)$ & $8(9.5)$ & $3(7.5)$ & 0.758 \\
\hline ALL L2 & $98(79.0)$ & 67 (79.5) & $31(77.5)$ & \\
\hline NS & $15(12.0)$ & $9(11.0)$ & $6(15.0)$ & \\
\hline \multicolumn{5}{|l|}{ Clinical features* } \\
\hline Lymphadenopathy (\%) & $69(63.5)$ & $48(57.0)$ & $21(84.0)$ & 0.014 \\
\hline $\begin{array}{l}\text { Splenomegaly, } \\
\geqslant 2 \mathrm{~cm}(\%)\end{array}$ & $43(40.0)$ & $32(39.0)$ & $11(44.0)$ & 0.657 \\
\hline Hepatomegaly, & $27(27.0)$ & $17(22.5)$ & $10(40.0)$ & 0.084 \\
\hline \multicolumn{5}{|l|}{ Laboratory data } \\
\hline Leukocyte count & 27325 (510- & 21700 & 50500 & \\
\hline Median (range), / $\mu \mathrm{l}$ & $513050)$ & $\begin{array}{c}(510- \\
450000)\end{array}$ & $\begin{array}{c}(600- \\
513050)\end{array}$ & \\
\hline$<50000 / \mu l$ & $77(62.0)$ & $58(69.0)$ & $19(47.5)$ & 0.021 \\
\hline$\geqslant 50000 / \mu l$ & $47(38.0)$ & $26(31.0)$ & $21(52.5)$ & \\
\hline Hemoglobin level* & 7.3 & 6.9 & 9.2 & \\
\hline Median (range), g/dl & $(3.0-15.4)$ & $(3.0-12.8)$ & $(4.7-15.4)$ & \\
\hline$<10 \mathrm{~g} / \mathrm{dl}$ & $86(81.0)$ & $72(89.0)$ & $14(56.0)$ & 0.001 \\
\hline$\geqslant 10 \mathrm{~g} / \mathrm{dl}$ & $20(19.0)$ & $9(11.0)$ & $11(44.0)$ & \\
\hline Platelet count* & 32500 & 30000 & 51000 & \\
\hline Median (range), / $\mu \mathrm{l}$ & $(2000-$ & $(2000-$ & (10 000- & \\
\hline$<10$ & & & & \\
\hline$\geqslant 100$ & & & & 0.220 \\
\hline Cytogenetic** & & & & \\
\hline Normal & $30(35.5)$ & $19(29.0)$ & $11(55.0)$ & 0.035 \\
\hline Abnormal & $55(65.0)$ & $46(71.0)$ & $9(45.0)$ & \\
\hline $\mathrm{Ph}$ & $18(21.0)$ & $18(27.5)$ & $0(0.0)$ & 0.008 \\
\hline $\mathrm{t}(4.11)$ & $4(4.5)$ & $4(6.0)$ & $0(0.0)$ & 0.569 \\
\hline Unsuccessful karyotype & $11(11.5)$ & $6(8.5)$ & $5(20.0)$ & \\
\hline
\end{tabular}

*Complete data are available for 107 cases including 82 cases of B-ALL and 25 cases for T-ALL.

${ }^{\star *}$ Cytogenetic data are available for 96 cases including 71 cases of B-ALL and 25 cases for T-ALL.

NS - not specified; FAB - French-American-British classification; Ph - Philadelphia chromosome.

Comparison of clinical characteristics in T-cell maturational stages. The main clinical characteristics of the 40 patients divided into three immune subtypes according to the pattern of antigens expression are summarized in Table 3 . As the number of patients was relatively small and for the purpose of statistic comparison we arbitrarily defined two groups: immature group (pro-T and pre-T ALL stages) and mature group (cortical-T and medullary-T stages). As shown in Table 3, patients in the mature group had a significantly high initial white cell count (more than $50000 / \mu \mathrm{l}$ ) than those in the immature group $(59.0 \%$ vs $28.0 \%$, $p=0.048)$. In contrast, no significant difference was observed between the two groups in regard to the others initial characteristics such age, sex, platelets, hemoglobin levels, organ (lymph nodes, liver and spleen) enlargement and cytogenetic findings.

Table 3. Characteristics of the 40 consecutive patients with T-ALL (n, \%)

\begin{tabular}{|c|c|c|c|c|c|}
\hline \multirow[t]{2}{*}{ Variable } & $\begin{array}{l}\text { Immature } \\
\text { (Pro- and } \\
\text { pre-T) }\end{array}$ & Cortical-T & Medullary-T & Mature & \multirow[t]{2}{*}{$p$} \\
\hline & $18(45.0)$ & $12(30.0)$ & $10(25.0)$ & $22(55.0)$ & \\
\hline \multicolumn{6}{|l|}{ Age } \\
\hline Median & $28(18-66)$ & $23(18-58)$ & $27(19-49)$ & $28(18-66)$ & \\
\hline$\leqslant 35$ & $11(61.0)$ & $10(83.5)$ & $9(90.0)$ & $19(86.5)$ & 0.140 \\
\hline$>35$ & $7(39.0)$ & 2 (16.5) & $1(10.0)$ & 3 (13.5) & \\
\hline \multicolumn{6}{|l|}{ Sex } \\
\hline male & $12(66.5)$ & $9(75.0)$ & $8(80.0)$ & $17(77.5)$ & 0.455 \\
\hline female & $6(33.5)$ & $3(25.0)$ & $2(20.0)$ & $5(22.5)$ & \\
\hline \multicolumn{6}{|l|}{ FAB } \\
\hline ALL L1 & $2(11.0)$ & $0(0.0)$ & $1(10.0)$ & $1(4.5)$ & 0.332 \\
\hline ALL L2 & $12(66.5)$ & $11(92.0)$ & $8(80.0)$ & 19 (86.5) & \\
\hline NS & $4(22.0)$ & $1(8.5)$ & $1(10.0)$ & $2(9.0)$ & \\
\hline \multicolumn{6}{|l|}{$\begin{array}{l}\text { Clinical fea- } \\
\text { tures* }\end{array}$} \\
\hline $\begin{array}{l}\text { Lymphadenopa- } \\
\text { thy }(\%)\end{array}$ & $6(75.0)$ & $11(91.5)$ & $4(80.0)$ & $15(88.0)$ & 0.570 \\
\hline $\begin{array}{l}\text { Splenomegaly, } \\
\geqslant 2 \mathrm{~cm}(\%)\end{array}$ & $3(30.0)$ & $5(62.5)$ & $3(43.0)$ & $8(53.5)$ & 0.414 \\
\hline $\begin{array}{l}\text { Hepatomegaly, } \\
\geqslant 2 \mathrm{~cm}(\%) \\
\text { Leukocyte count }\end{array}$ & $4(44.5)$ & $4(40.0)$ & $2(33.5)$ & $6(37.5)$ & 1.000 \\
\hline Median (range), / $\mu \mathrm{l}$ & $\begin{array}{c}21900 \\
(600- \\
513050)\end{array}$ & $\begin{array}{c}49800 \\
(1060- \\
496000)\end{array}$ & $\begin{array}{l}125450 \\
(8880- \\
253000)\end{array}$ & $\begin{array}{c}79875 \\
(1060- \\
496000)\end{array}$ & \\
\hline$<50000 / \mu l$ & $13(72.0)$ & $6(50.0)$ & $3(30.0)$ & $9(41.0)$ & 0.048 \\
\hline $\begin{array}{l}\geqslant 50000 / \mu l \\
\text { Hemoglobin level }\end{array}$ & $5(28.0)$ & $6(50.0)$ & $7(70.0)$ & $13(59.0)$ & \\
\hline Median (range), & 7.2 & 10.0 & 10.15 & 10.0 & \\
\hline $\mathrm{g} / \mathrm{dl}$ & $(4.7-14.20)$ & $(5.0-15.40)$ & $(7.10-12.50)$ & $(5.0-15.40)$ & \\
\hline$<10 \mathrm{~g} / \mathrm{dl}$ & $7(78.0)$ & $4(40.0)$ & $3(50.0)$ & $7(44.0)$ & 0.208 \\
\hline$\geqslant 10 \mathrm{~g} / \mathrm{dl}$ & $2(22.0)$ & $6(60.0)$ & $3(50.0)$ & $9(56.0)$ & \\
\hline \multicolumn{6}{|l|}{ Platelet count* } \\
\hline \multirow[t]{2}{*}{ Median (range), $/ \mu l$} & 70000 & 50000 & 50000 & 50000 & \\
\hline & (16000- & (10 000- & (13 000- & (10 000- & \\
\hline$<100000 / \mu \mathrm{l}$ & $5(62.5)$ & $7(70.0)$ & $\begin{array}{l}131000) \\
6(85.5)\end{array}$ & $\begin{array}{l}236000) \\
13(76.5)\end{array}$ & 0.640 \\
\hline$\geqslant 100000 / \mu l$ & $3(37.5)$ & $3(30.0)$ & $1(14.5)$ & $4(23.5)$ & \\
\hline Cytogenetic* & & & & & \\
\hline Normal & $5(55.5)$ & $2(20.0)$ & $3(50.0)$ & $5(31.5)$ & 0.458 \\
\hline Abnormal & $3(33.5)$ & $5(50.0)$ & $2(33.5)$ & $7(44.0)$ & \\
\hline Echec & $1(11.0)$ & $3(30.0)$ & $1(16.5)$ & $4(25.0)$ & \\
\hline
\end{tabular}

* Complete data are available for 25 cases.

NS - not specified; FAB - French-American-British classification.

$p$-value indicated that when comparing the immature group and the mature group. The immature group was consisted of pro-T and pre-T stage, and the mature group was consisted of cortical-T and medullary-T stage.

Clinical characteristics in relation to TdT, CD34 and myeloid antigens expression in T ALL. No significant association was encountered between CD34, TdT or myeloid antigens positivity and the presenting clinical and biological features studied (Table 4) apart a statistical significance association between myeloid antigens expression and T-cell maturation stages as $63.5 \%$ of the cases expressing myeloid associated markers were of the immature phenotype compared with $22 \%$ of the myeloid antigens negative cases $(p=0.009)$.

$\mathrm{T}-\mathrm{ALL} / \mathrm{LBL}$ is an aggressive neoplasm derived from T-cell progenitors. The disease can initially present as lymphoblastic lymphoma involving thymus, nodal, and extranodal sites, and/or as ALL involving primarily PB and BM. This work constitutes the first study to be carried out in Morocco involving characterization of the immunophenotypic profile of cases of adult 
T-ALL. Our results on the frequency of T-ALL (31\%) subtype was close to the frequency reported by some authors for France (28.5\%) [7] and Italy (26.0\%) [8] but this frequency was higher to the values found in USA (20.0\%) [9] and lower than the percentage reported for Egypt (50\%) [10] and India (53.0\%) [11]. The reason for the differences in the frequency of T-cell immunophenotype is unclear. According some publications, T-ALL is more commonly associated with low socioeconomic status [12].

When we analyzed the association between clinical and laboratory findings with T-ALL and B-ALL immunophenotypic subtypes of ALL, we could confirm previously published data [13-15] indicating that T-ALL occurs more frequently in males younger than 35 years of age and is usually accompanied by a high WBC count and tumor mass. On the other hand, we confirmed that leukemia of the T-cell lineage is commonly associated with a normal karyotype [16].

Immunophenotyping is essential in the diagnostic workup of T-ALL/LBL. Lymphoblasts express cytoplasmic and/or surface CD3 and other T-lineage makers (CD1a, CD2, CD4, CD5, CD7 or CD8) as well as one or more markers of immaturity, including CD1a, CD10, CD34 and terminal deoxynucleotidyl transferase (TdT). The latter is a unique intranuclear DNA polymerase that catalyzes the template-independent addition of deoxynucleotides to the 3 '-hydroxyl terminus of oligonucleotide primers [17] causing insertion of $\mathrm{N}$ regions during immunoglobulin and T-cell receptor (TCR) gene rearrangements at the DJ and VDJ junction sites [18, 19]. This mechanism of junctional diversity is essential to the development of an adult-type immunoglobulin and TCR repertoire [19]. The presence, frequency, and clinical significance of TdT in T-ALL have not been examined extensively. In this study, TdT was expressed in $50.0 \%$ of our patients with T-ALL. This expression was lower than that detected in recent studies conducted by Zhou et al. [20] and Patel et al. [21] who detected TdT expression in about $90.0 \%$ of T-ALL cases. The reasons for the differences may be attributed to different sensitivities of the antibodies as well as different cut-off levels for the discrimination of positive and negative cases. Others methodological variations in detection of TdT expression like fluorochrome labeling, varying gates in flow cytometric analysis and different TdT antibodies recognizing distinct TdT epitopes must also be taken in consideration when comparing studies on the implications of TdT expression. On th other hand, TdT negative cases should be carefully differentiated from mature T-cell neoplasms particularly in cases that are also negative for HLA-DR and CD34.

Table 4. Presenting clinical and biological features in relation to TdT, CD34 and myeloid antigens (CD13 and/or CD33) expression in the studied adult T-ALL patients (n, \%)

\begin{tabular}{|c|c|c|c|c|c|c|c|c|c|}
\hline Variable & $\frac{\mathrm{TdT}+}{19(50.0)}$ & $\frac{\text { TdT- }}{19(50.0)}$ & $p$ & $\begin{array}{c}\text { CD34+ } \\
23(57.5)\end{array}$ & $\begin{array}{c}\text { CD34- } \\
17(42.5) \\
\end{array}$ & $p$ & $\begin{array}{c}\mathrm{MyAg}+ \\
22(55.0)\end{array}$ & $\frac{\text { MyAg- }}{18(45.0)}$ & $p$ \\
\hline \multicolumn{10}{|l|}{ Age } \\
\hline Median & $28(18-66)$ & $27(18-50)$ & & $31(18-66)$ & $25.5(18-58)$ & & $30(19-66)$ & $24(18-49)$ & \\
\hline $\begin{array}{l}\leqslant 35 \\
>35\end{array}$ & $\begin{array}{c}14(73.5) \\
5(26.5)\end{array}$ & $\begin{array}{l}16(84.0) \\
3(16.0)\end{array}$ & 0.693 & $\begin{array}{l}17(74.0) \\
6(26.0)\end{array}$ & $\begin{array}{l}13(76.5) \\
4(23.5)\end{array}$ & 1.000 & $\begin{array}{l}15(68.0) \\
7(32.0)\end{array}$ & $\begin{array}{c}15(83.5) \\
3(16.5)\end{array}$ & 0.464 \\
\hline \multicolumn{10}{|l|}{ Sex } \\
\hline $\begin{array}{l}\text { male } \\
\text { female } \\
\text { FAB }\end{array}$ & $\begin{array}{c}13(68.5) \\
6(31.5)\end{array}$ & $\begin{array}{l}14(73.5) \\
5(26.5)\end{array}$ & 0.721 & $\begin{array}{c}16(69.5) \\
7(30.5)\end{array}$ & $\begin{array}{c}13(76.5) \\
4(23.5)\end{array}$ & 0.730 & $\begin{array}{c}14(63.5) \\
8(36.5)\end{array}$ & $\begin{array}{c}15(83.5) \\
3(16.5)\end{array}$ & 0.286 \\
\hline ALL L1 & $0(0.0)$ & $3(16.0)$ & 0.104 & $1(4.5)$ & $2(12.0)$ & 0.595 & $3(13.5)$ & $0(0.0)$ & 0.265 \\
\hline ALL L2 & $17(89.5)$ & $12(63.0)$ & & $19(82.5)$ & $12(70.5)$ & & $16(72.5)$ & $15(85.5)$ & \\
\hline $\begin{array}{l}\text { NS } \\
\text { Clinical features* }\end{array}$ & $2(10.5)$ & $4(21.0)$ & & $3(13.0)$ & $3(17.5)$ & & $3(13.5)$ & $3(16.5)$ & \\
\hline \multicolumn{10}{|l|}{ Clinical features* } \\
\hline Lymphadenopathy (\%) & $10(100.0)$ & $8(72.5)$ & 0.214 & $10(77.0)$ & 11 (91.5) & 0.593 & $9(75.0)$ & 12 (92.5) & 0.322 \\
\hline Splenomegaly, $\geqslant 2 \mathrm{~cm}(\%)$ & $7(50.0)$ & $4(40.0)$ & 0.697 & $6(37.5)$ & $5(55.5)$ & 0.434 & $6(40.0)$ & $5(50.0)$ & 0.697 \\
\hline Hepatomegaly, $\geqslant 2 \mathrm{~cm}(\%)$ & $4(28.5)$ & $6(60.0)$ & 0.211 & $5(31.5)$ & $5(55.5)$ & 0.397 & $3(23.0)$ & $7(58.5)$ & 0.111 \\
\hline \multicolumn{10}{|l|}{ Leukocyte count } \\
\hline Median (range), / $\mu \mathrm{l}$ & $\begin{array}{c}25000 \\
(1060- \\
205000)\end{array}$ & $\begin{array}{l}106000 \\
(6070- \\
513050)\end{array}$ & & $\begin{array}{c}66000(600- \\
513050)\end{array}$ & $\begin{array}{c}41000 \text { (1060- } \\
496050)\end{array}$ & & $\begin{array}{c}21900(600- \\
513050)\end{array}$ & $\begin{array}{c}79875(1060- \\
496000)\end{array}$ & \\
\hline$<50000 / \mu l$ & $12(63.0)$ & $9(47.5)$ & 0.328 & $11(48.0)$ & $11(64.5)$ & 0.289 & $14(63.5)$ & $8(44.5)$ & 0.225 \\
\hline $\begin{array}{l}\geqslant 50000 / \mu l \\
\text { Hemoglobin level }\end{array}$ & & \\
\hline Median (range), g/dl & $\begin{array}{c}9.5 \\
(4.7-15.40)\end{array}$ & $\begin{array}{c}8.85 \\
(7.10-14.20)\end{array}$ & & $\begin{array}{c}7.5 \\
(4.70-14.20)\end{array}$ & $\begin{array}{c}10.9 \\
(8.00-15.40)\end{array}$ & & $\begin{array}{c}7.6 \\
(4.70-14.20)\end{array}$ & $\begin{array}{c}10 \\
(5.0-15.40)\end{array}$ & \\
\hline$<10 \mathrm{~g} / \mathrm{dl}$ & $8(53.5)$ & $4(50.0)$ & 1.000 & $12(70.5)$ & $2(25.0)$ & 0.032 & $10(71.5)$ & $4(36.5)$ & 0.116 \\
\hline$\geqslant 10 \mathrm{~g} / \mathrm{dl}$ & $7(46.5)$ & $4(50.0)$ & & $5(29.5)$ & $6(75.0)$ & & $4(28.5)$ & $7(63.5)$ & \\
\hline \multicolumn{10}{|l|}{ Platelet count* } \\
\hline \multirow[t]{2}{*}{ Median (range), / $\mu l$} & 52000 & 35000 & & 52000 & 50000 & & 52000 & 50000 & \\
\hline & $\begin{array}{l}(12000- \\
236000)\end{array}$ & $\begin{array}{l}\left(\begin{array}{l}10 \\
000- \\
131000\end{array}\right)\end{array}$ & & $\begin{array}{l}(10000- \\
167000)\end{array}$ & $\begin{array}{l}(12000- \\
236000)\end{array}$ & & $\begin{array}{l}(12000- \\
167000)\end{array}$ & $\begin{array}{l}(10000- \\
236000)\end{array}$ & \\
\hline$<100000 / \mu \mathrm{l}$ & $10(77.0)$ & $7(78.0)$ & 1.000 & $13(76.5)$ & $5(71.5)$ & 1.000 & $10(77.0)$ & $8(73.0)$ & 1.000 \\
\hline$\geqslant 100000 / \mu \mathrm{l}$ & $3(23.0)$ & $2(22.0)$ & & $4(23.5)$ & $2(28.5)$ & & $3(23.0)$ & $3(27.0)$ & \\
\hline \multicolumn{10}{|l|}{ Cytogenetic* } \\
\hline Normal & $7(46.5)$ & $3(43.0)$ & 0.896 & $7(46.5)$ & $3(30.0)$ & 0.659 & $5(38.5)$ & $5(42.0)$ & 0.923 \\
\hline Abnormal & $5(33.5)$ & $3(43.0)$ & & $5(33.5)$ & $5(50.0)$ & & $5(38.5)$ & $5(42.0)$ & \\
\hline Echec & $3(20.0)$ & $1(14.0)$ & & $3(20.0)$ & $2(20.0)$ & & $3(23.0)$ & $2(16.0)$ & \\
\hline \multicolumn{10}{|l|}{ T cell stage* } \\
\hline Immature & $6(31.5)$ & $10(52.5)$ & 0.189 & $12(52.0)$ & $6(35.5)$ & 0.289 & $14(63.5)$ & $4(22.0)$ & 0.009 \\
\hline Mature & $13(68.5)$ & $9(47.5)$ & & $11(48.0)$ & $11(64.5)$ & & $8(36.5)$ & $14(78.0)$ & \\
\hline
\end{tabular}

${ }^{\star}$ Complete data are available for 25 cases. 
CD7 was always detected in our T-ALL series. Although it is one of the most sensitive T-cell marker, CD7 lacks specificity, as cases of AML or natural killer cell leukemia can express CD7 too [22]. In the current WHO classification system [2], CD3 expression is considered the only $\mathrm{T}$-cell lineage-specific marker and is required for $\mathrm{T}$-cell lineage assignment.

CD10 was detected in $14.0 \%$ of the T-ALL cases and CD34 was expressed in 57.5\% of cases. The CD10 antigen was originally known as common ALL antigen (cALLA). It was one of the first markers to identify acute leukemia in children. In the hematopoietic system, CD10 regulates stromal dependent B lymphopoiesis. The majority of B-lineage ALL cases expressed CD10. However, expression of CD10 has also been reported in other types of leukemia [23]. CD34 is a human stage-specific hematopoietic differentiation antigen, and expressed in early-undifferentiated hematopoietic stem cells, both in lymphoid and myeloid pathways. In leukemic cells, it remains expressed over several stages of lymphoid and myeloid maturation [24, 25]. In our study, the incidence of CD34 expression appeared to be more frequent on B-ALL (77.5\%) than T-ALL (57.5\%). This is consistent with previous observations in both children [26-28] and adult series [22, 29], suggesting a more immature hematopoietic cell involvement in B-ALL.

According to the stages of normal thymocyte development that they resemble, we stratified our 40 adult T-ALL cases into three maturational groups. The majority of cases (45.0\%) arise from immature compartment (pro-T and pre-T ALL). This finding is in agreement with previous reports $[30,31]$. Two recent studies have shown that a subset of T-ALL/LBL cases with an immunophenotype considered being of an early T-precursor origin (ETP) belongs to a very high risk group. The ETP immunophenotype is described as lack of CD1 a and CD8, CD5-/weak, and expression of one or more myeloid or stem cell-related antigens $[5,6]$. Both studies focused on pediatric patients and showed that ETP-positive cases represent $5-13 \%$ of T-ALL/LBL patients. In our study, we found that 6 cases (15.0\%) met the criteria for early T-cell immunophenotype defined by the following immunoprofile: CD1a-, CD8-, and $\mathrm{CD}^{+}$/weak with positivity for myeloid (CD13 and/ or CD33) or stem cell (CD34) antigens.

Malignant blasts often have an abnormal phenotype that allows distinction from normal immature cells. One of these abnormalities is the occurrence of aberrant phenotypes (or anomalous expression) which is defined by the co-expression of markers usually not present on cells of that particular lineage [32]. The frequency of aberrant expression of the B-cell antigen receptor complex associated protein CD79a in our T-ALL cases was $20.5 \%$ wish was higher than $5.0 \%$ recently reported by Patel et al. [21]. The finding of CD3/CD79a coexpression in ALL raises the question of whether these CD79a positive cases are genuinely of T-cell lineage. Pilozzi et al. [33] performed gene rearrangement studies of the immunoglobulin heavy chain and TCR gamma genes in a series of $C D 3^{+} \mathrm{ALL}$ with or without CD79a expression detected by immunohistochemistry. All of the cases studied showed TCR gamma gene rearrangement, and none showed solely immunoglobulin heavy chain gene rearrangement, strongly suggesting that $\mathrm{CD}^{+}$cases of ALL are of T-cell lineage, regardless of CD79a expression.

The incidence of aberrant myeloid antigen expression in our study is $55.0 \%$, an incidence much higher than reported previously for adult patients [21, 29, 31 ] but more close to $51.0 \%$ reported by Marks et al. [34]. Disparities in flow cytometric technology immunophenotyping could explain this different finding. The frequency of myeloid coexpression was comparable in B and in T-ALL $(52.5 \%$ vs $55.0 \%$, $p=0.744)$. This was different from earlier reports that My antigen was significantly associated with T cell ALL cases [35]. The role of myeloid associated antigens in the prediction of clinical outcome is still controversial. While the few early adult ALL studies had shown an inferior outcome for $\mathrm{My}^{+} \mathrm{ALL}$ patients [36-38] others have found similar outcomes [31, 35].

In conclusion, our findings indicate, first: that the overall immunoprofile of our T-ALL is generally similar to that described in small case series reports [39-41], second: the proportion of T-ALL among ALL in Morocco is similar to that reported in others Mediterranean countries like France and Italy. Third, the expression of myeloid-associated antigens is associated with immature immunophenotype of blast cells.

\section{REFERENCES}

1. Pui $\mathrm{CH}$, Evans WE. Acute lymphoblastic leukemia. N Engl J Med 1998; 339: 605-15.

2. WHO classification of tumours of haematopoietic and lymphoid tissues. S Swerdlow, $N$ Harris, E Jaffe, et al., eds. IARC: Lyon, 2008.

3. Craig FE, Foon KA. Flow cytometric immunophenotyping for hematologic neoplasms. Blood 2008; 111: 3941-67.

4. Lahjouji A, Bachir F, Bennani S, et al. Clinical importance of myeloid antigen expression in Moroccan patients with adult B-lineage acute lymphoblastic leukemia. Neoplasma 2013; 60: 553-60.

5. Inukai $\mathrm{T}$, Kiyokawa $\mathrm{N}$, Campana $\mathrm{D}$, et al. Clinical significance of early T-cell precursor acute lymphoblastic leukaemia: results of the Tokyo Children's Cancer Study Group Study L99-15. Br J Haematol 2012; 156: 358-65.

6. Coustan-Smith E, Mullighan CG, Onciu M, et al. Early T-cell precursor leukaemia: a subtype of very high-risk acute lymphoblastic leukaemia. Lancet Oncol 2009; 10: 147-56.

7. Boucheix C, David B, Sebban C, et al. Immunophenotype of adult acute lymphoblastic leukemia, clinical parameters, and outcome: an analysis of a prospective trial including 562 tested patients (LALA87). French Group on Therapy for Adult Acute Lymphoblastic Leukemia. Blood 1994; 84: 1603-12.

8. Foa R, Baldini L, Cattoretti G, et al. Multimarker phenotypic characterization of adult and childhood acute lymphoblastic leukaemia: an Italian multicentre study. Br J Haematol 1985; 61: 251-9.

9. Ross CW, Stoolman LM, Schnitzer B, et al. Immunophenotypic aberrancy in adult acute lymphoblastic leukemia. Am J Clin Pathol 1990; 94: 590-9. 
10. Kamel AM, Assem MM, Jaffe ES, et al. Immunological phenotypic pattern of acute lymphoblastic leukaemia in Egypt. Leuk Res 1989; 13: 519-25.

11. Rajalekshmy KR, Abitha AR, Pramila R, et al. Immunophenotyping of acute lymphoblastic leukaemia in Madras, India. Leuk Res 1994; 18: 183-90.

12. Paes CA, Viana MB, Freire RV, et al. Direct association of socio-economic status with T-cell acute lymphoblastic leukaemia in children. Leuk Res 2003; 27: 789-94.

13. Garand R, Vannier JP, Bene MC, et al. Comparison of outcome, clinical, laboratory, and immunological features in 164 children and adults with T-ALL: The Groupe d'Etude Immunologique des Leucemies. Leukemia 1990; 4: 739-44.

14. Hoelzer D, Gokbuget N. Recent approaches in acute lymphoblastic leukemia in adults. Crit Rev Oncol Hematol 2000; 36: 49-58.

15. Onciu M, Lai R, Vega F, et al. Precursor T-cell acute lymphoblastic leukemia in adults: age-related immunophenotypic, cytogenetic, and molecular subsets. Am J Clin Pathol 2002; 117: 252-8.

16. Uckun FM, Gajl-Peczalska KJ, Provisor AJ, et al. Immunophenotype-karyotype associations in human acute lymphoblastic leukemia. Blood 1989; 73: 271-80.

17. Onciu M, Lorsbach RB, Henry EC, et al. Terminal deoxynucleotidyl transferase-positive cells in reactive lymph nodes from children with malignant tumors: incidence, distribution pattern, and immunophenotype in 26 patients. Am J Clin Pathol 2002; 118: 248-54.

18. Alt FW, Baltimore D. Joining of immunoglobulin heavy chain gene segments: implications from a chromosome with evidence of three D-JH fusions. Proc Natl Acad Sci USA 1982; 79: 4118-22.

19. Cilfillan S, Dierich A, Lemeur M, et al. Mice lacking TdT: mature animals with an immature lymphocyte repertoire. Science 1993; 261: 1175-8.

20. Zhou Y, Fan X, Routbort M, et al. Absence of terminal deoxynucleotidyl transferase expression identifies a subset of high-risk adult T-lymphoblastic leukemia/lymphoma. Modern Pathology 2013; 26: 1338-45.

21. Patel JL, Smith LM, Anderson J, et al. The immunophenotype of T-lymphoblastic lymphoma in children and adolescents: a Children's Oncology Group report. Br J Haematol 2012; 159: 454-61.

22. Thalhammer-Scherrer R, Mitterbauer G, Simonitsch I, et al. The immunophenotype of 325 adult acute leukemias: relationship to morphologic and molecular classification and proposal for a minimal screening program highly predictive for lineage discrimination. Am J Clin Pathol 2002; 117: 380-9.

23. Faure GC. The GEIL (Groupe d'Etude Immunologique des Leucémies): CD10 in acute leukemias. Haematologica 1997; 82: 205-10.

24. Greaves MF, Brown J, Molgaard HV, et al. Molecular features of CD34: a hemopoietic progenitor cell-associated molecule. Leukemia 1992; 6 (Suppl): 131-6.

25. Schmitt C, Eaves CJ, Lansdorp PM. Expression of CD34 on human B cell precursors. Clin Exp Immunol 1991; 85: 168-73.
26. Tong $\mathrm{H}$, Wang $\mathrm{Q}$, Lu $\mathrm{C}$, et al. Immunophenotypic, cytogenetic, and clinical features of 207 cases of childhood acute lymphoblastic leukemia in China. J Pediatr Hematol Oncol 2011; 33: 437-41.

27. Dakka N, Bellaoui $\mathrm{H}$, Bouzid N, et al. CD10 and CD34 expression in childhood acute lymphoblastic leukemia in Morocco: clinical relevance and outcome. Pediatr Hematol Oncol 2009; 26: 216-31.

28. Bachir F, Bennani S, Lahjouji A, et al. Characterization of acute lymphoblastic leukemia subtypes in Moroccan children. Int J Pediatr 2009; 2009: 674801.

29. Czuczman MS, Dodge RK, Stewart CC, et al. Value of immunophenotype in intensively treated adult acute lymphoblastic leukemia. Cancer and Leukemia Group B Study 8364. Blood 1999; 93: 3931-9.

30. Shimizu H, Handa H, Hatsumi $N$, et al. Distinctive disease subgroups according to differentiation stages in adult patients with T-cell acute lymphoblastic leukemia. Eur J Haematol 2013; 90: 301-7.

31. Vitale A, Guarini A, Ariola C, et al. Adult T-cell acute lymphoblastic leukemia: biologic profile at presentation and correlation with response to induction treatment in patients enrolled in the GIMEMA LAL 0496 protocol. Blood 2006; 107: 473-9.

32. Ossenkoppele G, van de Loosdrecht A, Schuurhuis G. Review of the relevance of aberrant antigen expression by flow cytometry in myeloid neoplasms. Br J Haematol 2011; 153: 421-36.

33. Pilozzi E, Muller-Hermelink HK, Falini B, et al. Gene rearrangements in T-cell lymphoblastic lymphoma. J Pathol 1999; 188: 267-70.

34. Marks DI, Paietta EM, Moorman AV, et al. T-cell acute lymphoblastic leukemia in adults: clinical features, immunophenotype, cytogenetics, and outcome from the large randomized prospective trial (UKALL XII/ECOG 2993). Blood 2009; 114: 5136-45.

35. Vitale A, Guarini A, Ariola C, et al. Absence of prognostic impact of CD13 and/or CD33 antigen expression in adult acute lymphoblastic leukemia. Results of the GIMEMA ALL 0496 trial. Haematologica 2007; 92: 342-8.

36. Hoelzer D, Thiel E, Loffler H, et al. Prognostic factors in a multicenter study for treatment of acute lymphoblastic leukemia in adults. Blood 1988; 71: 123-31.

37. Guyotat D, Campos L, Shi ZH, et al. Myeloid surface antigen expression in adult acute lymphoblastic leukemia. Leukemia 1990; 4: 664-6.

38. Urbano-Ispizua A, Matutes E, Villamor N, et al. Clinical significance of the presence of myeloid associated antigens in acute lymphoblastic leukaemia. Br J Haematol 1990; 75: 202-7.

39. Lewis RE, Cruse JM, Sanders CM, et al. The immunophenotype of pre-TALL/LBL revisited. Exp Mol Pathol 2006; 81: 162-5.

40. Uyttebroeck A, Vanhentenrijk V, Hagemeijer A, et al. Is there a difference in childhood T-cell acute lymphoblastic leukaemia and T-cell lymphoblastic lymphoma? Leukaemia Lymphoma 2007; 48: 1745-54.

41. Hoelzer D, Gokbuget N. T-cell lymphoblastic lymphoma and T-cell acute lymphoblastic leukemia: a separate entity? Clin Lymphoma Myeloma 2009; 9: S214-S22. 